\title{
Clinical manifestations of chikungunya infection in the pediatric population: systematic review
}

\author{
Manifestações clínicas da infecção por chikungunya na população pediátrica: revisão \\ sistemática
}
Manifestaciones clínicas de la infección por chikungunya en la población pediátrica: revisión sistemática

Rodrigo Rufino Pereira Silva ${ }^{1 *}$, Sabrina Rufino Pereira Silva ${ }^{1}$, Luiz Custódio Moreira Junior ${ }^{1}$, Vanessa Lima Gonçalves ${ }^{1}$, Larissa Costa Araújo ${ }^{1}$, Renan Alexandre da Silveira Freire ${ }^{1}$, Cicero Gabriel Gonçalves Mota ${ }^{1}$, Wégila Fechine de Holanda Macêdo', João Roberto Braz Delmondes', Maria Lara Costa Araújo², Ramon de Sousa Feitosa1.

\begin{abstract}
Objective: To describe the clinical manifestations, especially those related to rheumatology, in the infant and neonatal population with Chikungunya viral, which are described in case studies in the literature. Methods: This is about a systematic review study, conducted according to the Preferred Reporting Items for Systematic Reviews and Meta-Analyzes (PRISMA) methodology. In order to identify the articles about the subject, the databases indexed to the BVS and SCIELO were searched, from June to July 2019, with the following search strategy: chikungunya virus and arthritis, arthralgia rheumatoid and chikungynya fever and arboviruses and arthralgia. Filters used included articles in English that have been published in the last 5 years. Manual searches were made in the bibliographic references of the articles found. Results: Six articles were reviewed, which addressed cases of Chikungunya confirmed pediatric patients. It was noticed that the main clinical manifestations were: fever, cutaneous symptoms, irritability and vomiting. Regarding rheumatologic symptoms, it was concluded that arthralgia and arthritis are uncommon in these patients, and residual arthritis is much less frequent in this age group. Conclusion: The control of the symptomatology and the dissemination of information related to the transmission of the virus helps in the promotion of health, and the complications of the disease must be known in time to be minimized.
\end{abstract}

Key words: Arthritis, Pediatrics, Chikungunya virus.

\section{RESUMO}

Objetivo: Descrever as manifestações clínicas, principalmente aquelas relacionadas à reumatologia, na população infantil e neonatal portadora de Chikungunya viral descritas em estudos de casos na literatura. Métodos: Trata-se de revisão sistemática, conduzida conforme a metodologia Preferred Reporting Items for Systematic Reviews and Meta-Analyses (PRISMA). Para identificar os artigos realizou-se busca nas bases de dados indexadas na BVS e na SCIELO, de junho a julho de 2019, com a seguinte estratégia de busca: vírus chikungunya e artrite, artralgia reumatoide e febre chikungunya e arboviroses e artralgia. Os filtros usados incluíram artigos em inglês e que fossem publicados nos últimos 05 anos. Buscas manuais foram feitas nas referências bibliográficas dos artigos encontrados. Resultados: Foram revisados 6 artigos que abordaram casos de pacientes pediátricos confirmados com Chikungunya. Verificou-se como principais manifestações clínicas: febre, sintomatologias cutâneas, irritabilidade e vômitos. Em relação aos sintomas reumatológicos, verifica-se que a artralgia e a artrite são incomuns nesses pacientes, além da artrite residual ser bem menos frequente nessa faixa etária. Conclusão: 0 controle da sintomatologia e a divulgação de informações relacionadas à transmissão do vírus auxiliam na promoção da saúde, devendo ser conhecidas a tempo as complicações da doença para estas serem minimizadas.

Palavras-chave: Artrite, Pediatria, Chikungunya Vírus.

${ }^{1}$ Faculdade Santa Maria (FSM), Cajazeiras - PB. *E-mail: rd_ro@hotmail.com

${ }^{2}$ Real Hospital Português da Beneficência, Recife - PE. 


\section{RESUMEN}

Objetivo: Describir las manifestaciones clínicas, principalmente aquellas relacionadas a la reumatología, en la población infantil y neonatal portadora de Chikungunya viral descritas en estudios de casos en la literatura. Métodos: Se trata de una revisión sistemática, conducida conforme a la metodología Preferred Reportingltems for Systematic Reviews y Meta-Analys (PRISMA). Para identificar los artículos se realizó una búsqueda en las bases de datos indexadas en la BVS y en SCIELO, de junio a julio de 2019, con la siguiente estrategia de búsqueda: Virus de chikungunya y artritis, artralgia reumatoide y fiebre de chikungynya y arbovirus y artralgia.. Los filtros usados incluyeron artículos en inglés y que se publicaron en los últimos 5 años. Se realizaron búsquedas manuales en las referencias bibliográficas de los artículos encontrados. Resultados: Se revisaron 6 artículos que abordaron casos de pacientes pediátricos confirmados con Chikungunya. Se verificó como principales manifestaciones clínicas: fiebre, sintomatologías cutáneas, irritabilidad y vómitos. En cuanto a los síntomas reumatológicos, se observa que la artralgia y la artritis son inusuales en estos pacientes, además de que la artritis residual es mucho menos frecuente en este grupo de edad. Conclusión: El control de la sintomatología y la divulgación de informaciones relacionadas a la transmisión del virus auxilian en la promoción de la salud, debiendo ser conocidas a tiempo las complicaciones de la enfermedad para éstas ser minimizadas.

Palabras clave: Artritis, Pediatría, Chikungunya Virus.

\section{INTRODUCTION}

Chikungunya Virus (CHIKV) is an arbovirus transmitted by a vector of the Alphavirus genus. The CHIKV and transmission to humans is usually carried out by mosquitoes of the Aedes genus, either in children or in adults. Reports from Nigeria and Uganda implicate Mansonia spp. mosquitoes as other likely vectors (DUARTE MCMB et al., 2016).

In 2019, until the epidemiological week no 12 (12/30/2018 to 03/23/2019), were 15,352 probable cases of chikungunya in the country, with an incidence of 7.4 cases $/ 100$ thousand inhabitants. CHIKV, which is popularly characterized by acute and chronic joint inflammatory manifestations, is responsible for large periodic epidemics in endemic and non-endemic areas where competent mosquitoes are present. Transmission of CHIKV by transfusion during outbreaks of explosives has never been documented, and the true impact of CHIKV infection on blood transfusion during an outbreak is unknown (APPASSAKIJ H et al., 2019; BRASIL, 2019).

CHIKV is considered a public health problem due to its rapid spread and high morbidity. The incapacitating nature of the disease has caused a substantial economic burden and collapse in health systems. The local transmission of CHIKV has been reported in more than 100 countries and territories in Asia, Africa, Europe, and the Americas (VILLERO-WOLF Y et al., 2019. NOVAL MG et al., 2019).

The Chikungunya Virus is considered a public health problem due to its rapid spread and high morbidity. This study aimed to determine the genetic diversity and phylogenetic relationships of CHIKVs in Colombia. Regarding the incubation period, it is seen that there is no divergence with age.

This period is an average of 2-7 days (ranging from 1-12 days). Symptomatology is diverse, including chikungunya fever: high fever, severe arthralgia and myalgia, with headache, photophobia and rash. Asymptomatic infections are rare. This clinical presentation differs among infants, older children, adults and the elderly, with regard to the intensity of the symptoms and their heterogeneity, occurring at most in small children and in the elderly, and at least in children and older adults (BURT FJ et al., 2014; DUARTE MCMB et al., 2016).

The common manifestations of neonates and infants are abrupt onset of fever, rashes, swelling in the ankle and wrists. The most serious clinical manifestations are edema, bullous erythema, dermatitis, necrotizing enterocolitis, myocarditis, pericarditis, encephalitis, meningoencephalitis, respiratory distress, sepsis and encephalopathy, being this last one the most common clinical manifestation in newborns infected by vertical transmission (mother-child) (MÉNDEZ-DOMÍNGUEZ N et al., 2016; DUARTE MCMB et al., 2016). 
Thus, despite the almost scarce existence of articles on chikungunya infantile, especially reporting the specific and often unusual symptomatology of this age range, the objective of this study was to carry out a systematic review of the literature on the clinical manifestations of chikungunya infantile.

\section{METHODS}

This is about a systematic review study, conducted according to the methodology of the Preferential Reporting Items for Systematic Reviews and Meta-analyzes (PRISMA). In order to identify the articles on the subject, we searched in the BVS and SCIELO bases from June to July 2019 with the following search strategy: Chikungunya virus and arthritis, arthralgia rheumatoid and chikungynya fever and arboviruses and arthralgia. Key words were used in English. Manual searches were made in the bibliographic references of the articles found. In order to include the articles, the following articles were used: articles, whose focus was chikungunya, with children target population, published in the English, Portuguese or Spanish periodicals published in the last 5 years (2014-2019), with texts available in their entirety.

After consulting the databases and applying search strategies, studies that were duplicated in the databases were identified. All summaries were read. In cases where the summary reading was not sufficient to establish whether the article should be added to the survey, considering the defined inclusion criteria, the article was read in its entirety to determine its eligibility. When the summary was sufficient, the articles were selected and then the full version was obtained for confirmation of eligibility and inclusion in the study. For the extraction of data from the articles and analysis of the studies, which was made in a descriptive way, an instrument was elaborated containing the following information: authors, year of publication, place of publication, type of study, general symptoms presented and description of symptoms specifically rheumatic diseases.

Figure 1 - Identification and selection of articles for systematic review on the clinical manifestations of chikungunya viral, 2011 to 2019.

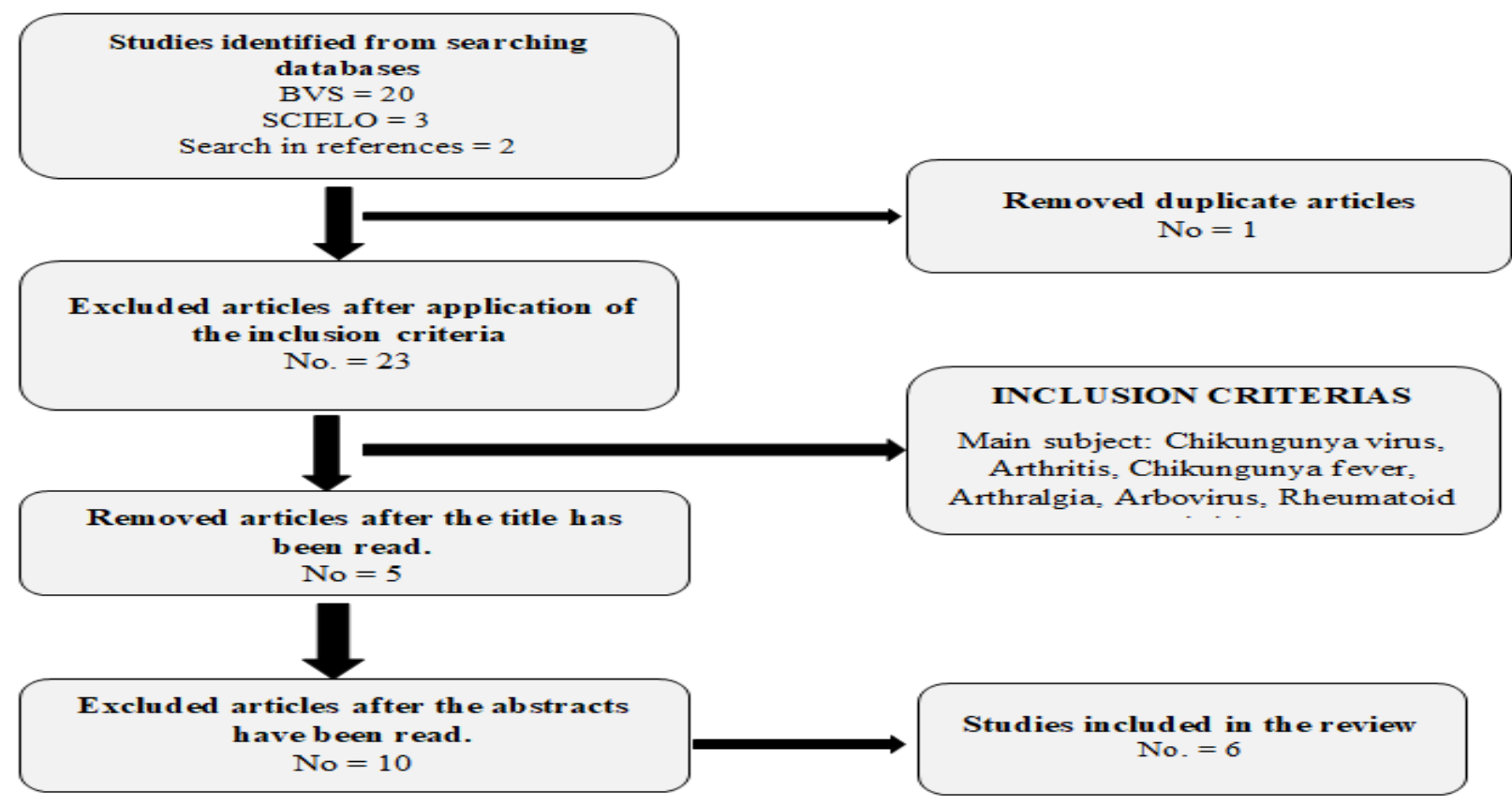

Source: Study data, 2019.

We found, in total, 25 articles. Were eliminated 1 duplicate article and 1 article after application of the inclusion criteria, thus, 23 were selected. When the main subject filter was used, 2 articles were excluded. There were 21 eligible articles, however 5 were excluded after the titles were read. After the abstracts were read, 10 articles were eliminated, because they did not present children in their studies. Two studies were 
found through the manual search in the references of the articles found. At the end, 6 articles were included in the present systematic review; these included studies with children. Figure 1 presents an overview of the article selection process. As for the general characteristics, the oldest publication was from 2011; the articles are from different regions from the Brazilian northeast to Southeast Asia. The descriptive analysis design was predominant, and the samples varied from only one case report to 370 suspected Chikungunya cases. Regarding the form of evaluation of the outcome, there were diversifications regarding the clinical picture that leads to the diagnostic suspicion of Chikungunya. Some studies consider arthritis / arthralgia as a criterion; to others only the presence of unexplained sudden onset fever and exposure to endemic areas was enough to be included in the study. Some articles, besides those that were mentioned, also added as a criterion the presence of cutaneous manifestations.

\section{RESULTS}

Regarding the laboratory findings, there was a high frequency of anemia, altered leukogram, increased cerebrospinal fluid cerebrospinal fluid, increased aminotransferases and creatinine phosphokinase (BAQUERO-LATORRE H, 2015; DUARTE MCMB et al., 2016). However, it is interesting to note that not all diagnostic suspicions were confirmed by laboratory tests, and because of the similarity with clinical manifestations with other pathologies, the studies may have included children whose Chikungunya diagnosis had been erroneously done.

Table 1 - Characteristics of studies in children with chikungunya, by author (s), year, place, type of study, general symptoms presented and specifically rheumatologic symptoms.

\begin{tabular}{|c|c|c|c|c|c|c|}
\hline ARTICLE NAME & AUTHORS & $\begin{array}{l}\text { YEAR OF } \\
\text { PUBLICATION }\end{array}$ & $\begin{array}{l}\text { PLACE OF } \\
\text { PUBLICAT } \\
\text { ION }\end{array}$ & $\begin{array}{l}\text { KIND OF } \\
\text { STUDY }\end{array}$ & $\begin{array}{l}\text { GENERAL } \\
\text { SYMPTOMS } \\
\text { PRESENTED }\end{array}$ & $\begin{array}{l}\text { SPECIFICALLY } \\
\text { RHEUMATOLOGIC } \\
\text { SYMPTOMS }\end{array}$ \\
\hline $\begin{array}{l}\text { Chikungunya: } \\
\text { A re-emerging virus }\end{array}$ & Burt et al. & 2014 & $\begin{array}{l}\text { South } \\
\text { Africa }\end{array}$ & $\begin{array}{l}\text { Bibliographic } \\
\text { Research }\end{array}$ & $\begin{array}{l}\text { Abrupt onset of } \\
\text { fever, rash, swollen } \\
\text { ankles and wrists, } \\
\text { neurological } \\
\text { complications, } \\
\text { fatigue }\end{array}$ & Arthralgia \\
\hline $\begin{array}{l}\text { Choque séptico secun- } \\
\text { dario a fiebre por } \\
\text { chikungunya no con- } \\
\text { génita en un lactante } \\
\text { menor: caso clínico }\end{array}$ & $\begin{array}{l}\text { Méndez- } \\
\text { Domingu } \\
\text { ez et al. }\end{array}$ & 2016 & Mexico & Case report & $\begin{array}{c}\text { Fever, Skin eruption, } \\
\text { Lethargy }\end{array}$ & - \\
\hline $\begin{array}{c}\text { Chikungunya infections } \\
\text { In infants }\end{array}$ & $\begin{array}{c}\text { Duarte et } \\
\text { al. }\end{array}$ & 2016 & Brazil & $\begin{array}{l}\text { Series of } \\
\text { cases study }\end{array}$ & $\begin{array}{c}\text { Fevers, Sking } \\
\text { changes, Irritability, } \\
\text { Vomit }\end{array}$ & $\begin{array}{l}\text { Arthritis and } \\
\text { Arthralgia }\end{array}$ \\
\hline $\begin{array}{l}\text { Chikungunya viral infec- } \\
\text { tions in pediatric } \\
\text { population: } \\
\text { Laboratory parameters and } \\
\text { clinical presentations }\end{array}$ & $\begin{array}{c}\text { Singh et. } \\
\text { Al }\end{array}$ & 2016 & India & $\begin{array}{l}\text { Series of } \\
\text { cases study }\end{array}$ & $\begin{array}{l}\text { Fever, Skin rashes, } \\
\text { Encephalitis, } \\
\text { Respiratory failure, } \\
\text { Liver failure and } \\
\text { Myocardial } \\
\text { involvement }\end{array}$ & $\begin{array}{c}\text { Disabling } \\
\text { polyarthralgia }\end{array}$ \\
\hline $\begin{array}{c}\text { La fiebre de Chikungunya } \\
\text { en el } \\
\text { Periodo neonatal }\end{array}$ & $\begin{array}{l}\text { Baquero- } \\
\text { Latorre }\end{array}$ & 2015 & Colombia & $\begin{array}{l}\text { Bibliographic } \\
\text { Research }\end{array}$ & $\begin{array}{l}\text { Prostration, fever, } \\
\text { encephalopathy, } \\
\text { meningoencephalitis } \\
\text {, generalized } \\
\text { desquamation, nasal } \\
\text { erythema, apnea, } \\
\text { shock, vesicular } \\
\text { lesions }\end{array}$ & Arthralgia \\
\hline $\begin{array}{c}\text { Emergence of chikungunya } \\
\text { in Moonlapamok and } \\
\text { Khong } \\
\text { Districts, Champassak } \\
\text { Province, } \\
\text { The Lao People's } \\
\text { Democratic } \\
\text { Republic, May to } \\
\text { September } 2012\end{array}$ & $\begin{array}{c}\text { Soulaphy } \\
\text { etal. }\end{array}$ & 2016 & $\begin{array}{l}\text { The Lao } \\
\text { People's } \\
\text { Democrat } \\
\text { ic } \\
\text { Republic }\end{array}$ & $\begin{array}{l}\text { Series of } \\
\text { cases study }\end{array}$ & $\begin{array}{l}\text { Fever, rash, and } \\
\text { depression }\end{array}$ & $\begin{array}{c}\text { Severe Arthralgias } \\
\text { or Arthritis }\end{array}$ \\
\hline
\end{tabular}

Source: Study data, 2019. 
All articles revised were complementary by stating that the clinical manifestations of Chikungunya in children have multisystemic involvement and are serious, often fatal, conditions. It was also noted that arthralgia / arthritis are affections that affect more adults. Children, on the other hand, presented as common symptoms fever, skin symptoms - present in all cases - constant irritability - present in $64.3 \%$ of the cases and, arthralgia / arthritis and vomiting - present in $35.7 \%$ of the cases.

Chikungunya is a disease that ranges from an asymptomatic disease to a debilitating disease, and its clinical manifestations are quite varied. Although it is rarely fatal, it presents rheumatic symptoms that can generate psychiatric disorders - such as depression - which are common and harmful. It is also observed that the clinical presentation differs between infants, preschool and school children, adults and the elderly in relation to the intensity of symptoms and their heterogeneity, occurring more frequently in younger children and in the elderly. (BURT et al., 2014; BAQUERO-LATORRE H, 2015).

Regarding CHIKV infection, in children, the fever usually starts suddenly and is of a high degree, reaching up to $40^{\circ} \mathrm{C}$. Rash is a manifestation that most patients develop; irritating maculopapular eruptions lasting about 48 hours are the most common manifestations and are mainly located in the arms, back and shoulders; occasionally over the entire body.

There are also other dermatological variations, such as pigmentary changes, for example. Facial hyperpigmentation (brown nose), which has been associated with thrombocytopenia in infected patients and newborns, has been described in recent reports (DUARTE MCMB et al., 2016; MÉNDEZ-DOMíNGUEZ N et al., 2016).

Undoubtedly, fever is an enigmatic symptom in this disease. It is known that fever in children younger than 2 months is usually associated with signs of severity, including bacterial infections that require specific treatment and may be aggravated if the antimicrobial treatment is delayed or not performed.

Thus, antipyretic treatment is generally not recommended without prior knowledge of the origin of the fever. Therefore, infants should receive specialized care to know and treat the disease adequately, even knowing that the use of non-steroidal anti-inflammatory drugs in ignorance of the etiology implies the risk of masking the underlying condition (MÉNDEZ-DOMÍNGUEZ N et al., 2016; SINGH A, 2016).

Usually, the infection is accompanied by symptoms such as: high fever, severe arthralgia, myalgia, headache, photophobia and rashes. The disease can be complicated by the occurrence of neurological manifestations, hemorrhagic manifestations and hemodynamic instability. Table 1 shows the main clinical manifestations referring to each article (BURT FJ et al., 2014; DUARTE MCMB et al., 2016; SOULAPHY C et al., 2013).

\section{DISCUSSION}

It is not thought that a classic case of chikungunya produces hemorrhagic manifestations. In contrast, in Calcutta (1963/64) (SARKAR JK et al., 1964) hemorrhagic manifestations were observed from gingival bleeding, hematemesis and melena to shock. In the attempt to characterize the hemorrhagic fever, studies were carried out in Thailand and Burma, where there was divergence as to the result of the research.

In studies in Thailand, it was found that, in children with hemorrhagic fever, only $7.6 \%$ had chikungunya. In the small ones with dengue, the incidence was almost $83 \%$ of the total cases. However, in Burma, a quarter of the total haemorrhagic fever in children was caused by chikungunya. Dengue was responsible for approximately $16 \%$ of the cases. It is worth mentioning that none of the children had a shock, but also that both studies found that hemorrhagic manifestations were less severe in chikungunya than in dengue fever (SUCHITRA N, 1969).

Although the Chikungunya virus is not considered a neurotropic virus, there is evidence of neurological impairment in patients with the infection. It should be noted that, in children, these complications were the most common cause of hospitalizations, being the most frequent example: encephalitis (the most common also in neonates infected with mother-to-child transmission) (RAVI MEHTA et al., 2018). 
Patient who, prior to infection, had rheumatoid arthritis was more susceptible to signs of erosive arthritis and narrowing of joint space. In the same perspective, the underlying disorders and the severity of pain at the moment of the disease are factors for the persistence of arthralgia, being characterized by fluctuations of intensity and recurrences predominantly in the same joints reached in the acute phase. It is worth noting that the chronic phase is less severe than the acute one, however there are reports of a reduction in the quality of life of the patient (DUARTE MCMB et al., 2016).

Differently from how it occurs in adults - of whom about $85 \%$ develop joint symptoms, which may be even disabling - in children, arthralgia and arthritis are uncommon, in addition to the fact that residual arthritis is much less frequent in this age group. Other manifestations include lymphadenopathy, swelling of the eyelids and pharyngitis, which are common. Headache and myalgia are frequent presenting symptoms. Aqueous faeces can be observed in infants (MÉNDEZ-DOMíNGUEZ $\mathrm{N}$ et al., 2016).

With regard to the neonatal period, maternal-fetal transmission by the chikungunya virus has been found to be infrequent at the population level. Exceptionally, this happens around the perinatal period, which comprises 4 days before birth and 1 day after. However, when there is viremia in the mother during delivery, the possibility of fetal infection is up to $50 \%$, and in neonates the percentage is the same as the development of complications due to the disease. However, it is worth noting that systematic caesarean section is not recommended for infected mothers if its purpose is to reduce the risk of viral transmission; the emergency cesarean also does not prevent the transmission of the disease. The mean duration between the onset of the disease in the mother and the baby is 5 days (DUARTE MCMB et al., 2016; MÉNDEZ-DOMíNGUEZ N et al., 2016).

\section{CONCLUSION}

It is concluded from the study that this emerging pathology should be more frequently focused, so that prevention and control measures can be expanded, which will strengthen health in the affected areas. This work will serve as a basis for public health research on chikungunya, encompassing etiology, incidence and prevention of diseases, vector mosquitoes and their control, and should therefore be distributed to the public and provided to health professionals so that they are aware of the potential dissemination and onset of this disease. It was also evidenced that in the literature there are still not many detailed studies that portray specific manifestations of the disease in the pediatric population, especially in the group of neonatal patients.

\section{ACKNOWLEDGMENTS AND FINANCING}

The authors are grateful for the support of Faculdade Santa Maria. This work was produced with own resources.

\section{REFERÊNCIAS}

1. APPASSAKIJ H, et al. The Potential Impact of Chikungunya Virus Outbreaks on Blood Transfusion. Transfusion Medicine Reviews. 2019; 33 (2): 69-79.

2. BAQUERO-LATORRE H. La fiebre de Chikungunyaenel período neonatal. Salud Barranquilla, $2015 ; 31$ (3): $642-$ 650.

3. BURT FJ, et al. Chikungunya: a re-emerging virus. The Lancet, 2014; 379 (9816): 662-671.

4. MÉNDEZ-DOMÍNGUEZ N, et al. Choque séptico secundario a fiebre por chikungunya no congénita enun lactante menor: caso clínico. Rev Child Pediatr, 2016; 87 (2): 143-147.

5. DUARTE MCMB, et al. Chikungunya infection in infants. Rev Bras Saude Matern Infant, 2016; 16(1): 63-71.

6. JUPP PG, et al. Laboratory vector studies on six mosquito and one tick species with chikungunya virus. Trans $R$ Soc Trop Med Hyg, 1981; 75(1): 15-19.

7. MOHER D, et al. PRISMA Group. Preferred reporting items for systematic reviews and meta-analyses: the PRISMA statement. Ann Intern Med, 2009; 151 (4): 264-9.

8. PELLOT AS, et al. Severe forms of chikungunya virus infection in a pediatric intensive care unit on Reunion Island. Medecine tropicale: revuedu Corps desante colonial, 2012; 72 (1): 88-93. 
9. RAVI MEHTA, et al. The neurological complications of chikungunya virus: A systematic review. Rev Med Virol. 2018. 28(3): 1978.

10. RITZ N, et al. Chikungunya in children. The Pediatric infectious disease journal, 2015; 34 (7): 789-91.

11. SINGH A. Chikungunya viral infections in pediatric population: laboratory parameters \& clinical

12. presentations, 2016; 10 (13140). doi: 10.13140/RG.2.2.19426.12489

13. SOULAPHY C, et al. Emergence of chikungunya in Moonlapamok and Khong Districts, Champassak Province, the Lao People's Democratic Republic, 2012; Western Pacific Surveillance and Response Journal: WPSAR, 2013; 4 (1): 46-50.

14. VILLERO-WOLF Y, et al. Genomic epidemiology of Chikungunya virus in Colombia reveals genetic variability of strains and multiple geographic introductions in outbreak, 2014. Scientific Reports, 2019; 9(1): 1-11.

15. NOVAL MG, et al. Evolution-Driven Attenuation of Alphaviruses Highlights Key Glycoprotein Determinants Regulating Viral Infectivity and Dissemination. Cell Resp.,2019; 28 (2): 460-471.

16. BRASIL. Ministério da Saúde. Boletim Epidemiológico da Secretaria de Vigilância em Saúde. $2019: 50$ (13).

17. SARKAR JK et al. Estudos virológicos e sorológicos de casos de febre hemorrágica em calcutta. material coletado pela escola de calcutta de medicina tropical. Indian J Med Res. 1964 Jul; 52 (1): 684-91.

18. SUCHITRA N et al. Infecção pelo Vírus da Dengue e Chikungunya no Homem na Tailândia, 1962-1964. Revista Americana de Medicina Tropical e Higiene , 1969; 18(6): 954 - 971. 